\title{
Improving Students' Motivation In English Vocabulary Mastery Through Mobile Learning
}

\begin{tabular}{ccc} 
& Nur Amalia Solikhah ${ }^{1}$ & \\
& & \\
& & \\
& & \\
& UBSI PSDKU Purwokerto & \\
\hline Diterima & Direvisi & Disetujui \\
$23-01-2020$ & $10-02-2020$ & $02-03-2020$ \\
\hline
\end{tabular}

\begin{abstract}
The objectives of this research is to improve the students' motivation through mobile phones as learning (m-learning) media in teaching vocabulary. This media is used to improve students' interest by giving attention to their teacher's vocabulary learning. English vocabulary that is considered challenging to study for students, it is the most crucial aspect of learning EFL. The respondents of this research are students of the Information System study program. This Action Research consists of two (2) cycles with five (5) actions in each cycle. In collecting the data, this research used multiple-choice as a test for English vocabulary mastery, observation to obtain data on students' activities, field note to record about the general classroom situations, and questionnaires to obtain information from the students in the sense of a report about their English vocabulary learning through mobile learning media. Based on the data analysis of pre-test, post-test 1 in the first cycle, post-test 2 in the second cycle, the mean score is 61.37, 66.06, and 73.42. Then, the data analysis of the observation list in the pre-cycle, the first cycle, and the second cycle is $42.18 \%, 49.47 \%$, and $70.97 \%$. It supports the questionnaire data that more than $70 \%$ of the students agreed that mobile learning media could motivate them and increasing their English vocabulary mastery. The result of this research showed that Mobile Phone as Learning Media is effective in improving students' motivation in English vocabulary mastery.
\end{abstract}

Keywords: Students' Motivation, Mobile Phone, Vocabulary Mastery

\begin{abstract}
Abstrak - Tujuan dari penelitian ini adalah untuk meningkatkan motivasi siswa melalui ponsel sebagai media pembelajaran (m-learning) dalam pengajaran kosa kata. Media ini digunakan untuk meningkatkan minat siswa dengan memberi perhatian pada pembelajaran kosa kata yang guru berikan. Kosakata bahasa Inggris yang dianggap sulit untuk dipelajari bagi siswa, merupakan aspek yang paling penting dari pembelajaran Bahasa Inggris sebagai bahasa asing. Responden dalam penelitian ini adalah mahasiswa program studi Sistem Informasi. Penelitian Tindakan ini terdiri dari dua (2) siklus dengan lima (5) tindakan dalam setiap siklus. Dalam mengumpulkan data, penelitian ini menggunakan pilihan ganda sebagai tes untuk penguasaan kosakata bahasa Inggris, observasi untuk memperoleh data kegiatan siswa, catatan lapangan untuk mencatat tentang situasi kelas secara umum, dan kuesioner untuk mendapatkan informasi dari siswa tentang pembelajaran kosakata bahasa Inggris mereka melalui media pembelajaran melalui ponsel. Berdasarkan analisis data pre-test, post-test 1 pada siklus pertama, post-test 2 pada siklus kedua, skor rata-rata adalah 61,37, 66,06, dan 73,42. Kemudian, analisis data dari daftar pengamatan di pra-siklus, siklus pertama, dan siklus kedua adalah 42,18\%, 49,47\%, dan 70,97\%. Data ini mendukung data kuesioner bahwa lebih dari 70\% siswa sepakat bahwa media pembelajaran melalui ponsel dapat memotivasi mereka dan meningkatkan penguasaan kosakata bahasa Inggris mereka. Hasil penelitian ini menunjukkan bahwa Ponsel sebagai Media Pembelajaran efektif dalam meningkatkan motivasi siswa dalam penguasaan kosakata bahasa Inggris.
\end{abstract}

Kata Kunci : Motivasi Siswa, Ponsel, Penguasaan Kosakata

\section{INTRODUCTION}

Vocabulary is one of the problematic aspects of English for students to master thoroughly; therefore, it most important in learning EFL. The students should concentrate on learning English vocabulary for their practical, real-life needs. So, vocabulary knowledge is crucial in learning English. It is essential that those working with students to motivate and help foster their development of a large "word bank" and effective vocabulary learning strategies through media.

The development of educational media is swift. One of these cannot be separated from technology. Through technological development, education is more advanced and more creative. The development of educational media in technologies, especially in using the mobile phone as learning media, is one of the familiar alternative development learning media at this time, namely mobile learning. 
The appearance of the mobile phone as learning media is impressive. The mobile phone, as learning media, can be used as a media to motivate students to learn English, especially learning vocabulary. So, English as a foreign language that is considered challenging to study vocabulary by the students is necessary for a mobile phone as a learning media application that can be applied as English learning media.

Due to the importance of learning vocabularies, teachers have an essential duty to create and maintain an exciting situation by providing a media that able to increase students' motivation, such as technology, as an English learning media. The teacher needs to explore more fully the factors that are involved in motivating students to perform tasks well because this is something that a teacher has some control over (Ellis, 1997). Therefore it is crucial to find out the possible underlying factors which affect students' motivation in English learning, especially in the practical sense to teachers who want to stimulate students' motivation. Also, Harmer says that if students continue to be intrinsically motivated, they need to be interested both in the subject they are studying and in the activities and topics they are presented with. The teacher needs to provide those learning strategies with a media and a variety of subjects that motivated them.

Another critical dimension in classification intrinsic and extrinsic motivation. Intrinsic means "from within." It means that learning is driven by the students' intrinsic motivation-curiosity and interest (the learning activity is as the reward for student). Extrinsic motivation, on the other hand, is focused on something external to the learning activities, and extrinsic motivation is encouraged by an outside force- teacher, teaching media, classroom situation. Extrinsic motivation, on the other hand, is carried out in anticipation of a reward from outside and beyond the self, which typically can be prizes, grades, and even certain types of positive feedback. It focuses on something external to the learning activities, and extrinsic motivation is encouraged by an outside force (De Brabander \& Martens, 2014).

Based on the reason above, to motivate students to improve English vocabularies, the teachers have carried students' motivation to refer to the students' desire to learn English vocabularies and English teaching media such as mobile phones as an alternative learning media of vocabularies' teaching. This application of mobile phones as learning media (m-learning) can display the material with pictures that are interesting to the students. The application can display the pages of exercises that can be done directly and easy to use for the students' practices. The application helped the students be more active in vocabulary learning participation by giving comments, suggestions in the task group (discussion).

\section{RESEARCH METHODOLOGY}

This research is classroom action research (CAR). Action research is systematic inquiry done by teachers (or other individuals in the teaching/learning environment) to gather information about and subsequently improve how their particular schools operate, how they teach, and how well their students learn. Action research is a systematic approach to investigation that enables people to find practical solutions to problems they confront in their everyday lives (Nasrollahi, 2015).

Action research is also a standard methodology employed for improving conditions and practice in the classroom and other practitionerbased environments such as administrative, leadership, social, and community settings. Through action research, teachers and others working in a practitioner-based environment use their expertise and knowledge to conduct a systematic inquiry that helps improve conditions and solve problems. As practitioners interact in the environment, they gain experience. They use this experience to inform practice. However, the experience must be matched with evaluative skills to improve the practising environment. Practical evaluation of a program, situation, or condition, which is, in essence, based on systematic analysis-can be facilitated through action research. Action research encourages the researcher to consider the interconnectedness of the environment and everyone in it, the conditions present in the environment, and the interactions among the individuals in the environment (Stone et al., 2002).

In collecting the data, this action research used some instruments. They are multiple-choice as a test for English vocabulary mastery, observation to obtain data on students' activities, field note to record about the general classroom situations, and questionnaires to obtain information from the students in the sense of a report about their English vocabulary learning through mobile learning media.

\section{FINDING AND RESULTS}

Instruction is the arrangement of information and the environment to facilitate learning. Media refers to anything that carries information between a source and a receiver. By the environment, instruction, and also method, media, and equipment needed to convey information and guide the students' learning process. The instructional media 
will carry massages with an instructional purpose that is to facilitate communication between teachers and students. Furthermore, it divides instructions media into some types (Heinich et al., 2012).

In this classroom, action research decided to use mobile learning as an instructional media mediated by a computer where can also be operated on android's mobile phone. Based on the expert's assumptions above, this research can assume that instructional media mediated by computer is the primary means of communicating that make students able to gain knowledge, skill or attitudes and use for effective communication more and interaction between the teacher and the students in the vocabulary learning process.

Pinkwart defines e-learning as 'learning supported by digital "electronic" tools and media,' and by analogy, mobile phones as learning as ' $\mathrm{e}$ learning that uses mobile devices and wireless transmission' (Pinkwart et al., 2003). Mobile phones as learning as only learning that takes place with the help of mobile devices (Boyinbode \& Akinyede, 2008). The mobile phone, as learning media wireless and digital devices and technologies, generally produced for the public, used by a learner participates in education (Traxler, 2007). It conceptualizes mobile phones as learning media refers to the capabilities of the technology within the physical contexts and activities of the students as they participate in learning institutions. It means activities of the learning process, the behaviour of the students as they use the technology to learn. It also refers to the attitudes of students who use mobile technology for learning purposes

Also, the emphasis on the students' experience when they use the mobile phone as learning media in the class, it can be used to make a unique contribution to the advancement of education and other forms of e-learning. The mobile phone as learning values and defends in its unique way to introduce learning material in the education, social, and cultural spheres of human life and activity. The mobile phone as new learning media in learning can be used to encourage the students to abandon the constraints of our habitual ways of thinking, learning, communicating, designing, and reacting. This argument provides a robust theoretical framework for understanding how mobile technology is useful in the vocabulary learning process in motivating the students.

Motivation has an essential role in learning English process to the students. Motivation is an effort that encourages someone to do something or motives power from within and in the subject to perform certain activities to achieve goals(Sardiman, 2016). Motivation is the energy change in a person who is marked by the appearance of feeling and preceded by a response to any destination. In the learning process, the students' motivation refers to the student's interest, desire, compulsion, and need to participate and be successful in the learning process. It means that the students' motivation plays a crucial role in the success of the learning process.

Vocabulary can be defined as the words of a language, including single items and phrases or chunks of several words which covey a particular meaning, the way individual words do. The word learning can be used to mean "the process of acquiring knowledge," like the learning that takes place in the classroom, but it also means the knowledge itself, such as learning about English vocabulary (Alfaki, 2015).

Vocabulary knowledge is often viewed as a critical tool for second language learners because a limited vocabulary in a second language impedes successful communication. Underscoring the importance of vocabulary acquisition emphasizes that "lexical knowledge is central to communicative competence and to the acquisition of a second language" Nation (Dorkchandra, 2016) further describes the relationship between vocabulary knowledge and language use as complementary: knowledge of vocabulary enables language use and, conversely, language use leads to an increase in vocabulary knowledge. The importance of vocabulary is demonstrated daily in and out of school. In the classroom, achieving students possess sufficient vocabulary.

In English as a second language (ESL) and English as a foreign language (EFL), learning vocabulary items play a vital role in all language skills (i.e., listening, speaking, reading, and writing) (Nation \& Hunston, 2013). The acquisition of an adequate vocabulary is essential for successful second language use because, without an extensive vocabulary, we will be unable to use the structures and functions we may have learned for comprehensible communication (ALQAHTANI, 2015).

The mobile phone as learning media that was used in education to make learning active and exciting. The mobile phone, as learning media, is implemented on tablets or mobile phones. Most tablets now include mobile phone functionalities. There are many reported successful usage of a mobile phone as learning media in schools. Mobile phones as learning media help students explore genetic concepts using a collaborative problemsolving approach. The Docklands Learning Acceleration Project aimed to increase the amount of the students' English learning competencies (Danesh et al., 2001).

The literature review generally presents a 
positive picture of m-learning in education. The mobile phone as learning media used to complete exercises that facilitate learning and to complete assessed work. Based on those reviews of previous relevant studies, this research designed mobile phones as learning media in English vocabulary learning media to motivate the students in order to mastery in English vocabulary (Stone et al., 2002).

According to the data during the research could be described that the percentage of the students' activeness in the observation list during the research was increased. It is shown by the positive changes since the pre-cycle to cycle one and cycle 2 in its every action. Based on the data on the previous page, the improvement of the students' activeness in each action is shown in the following figure.

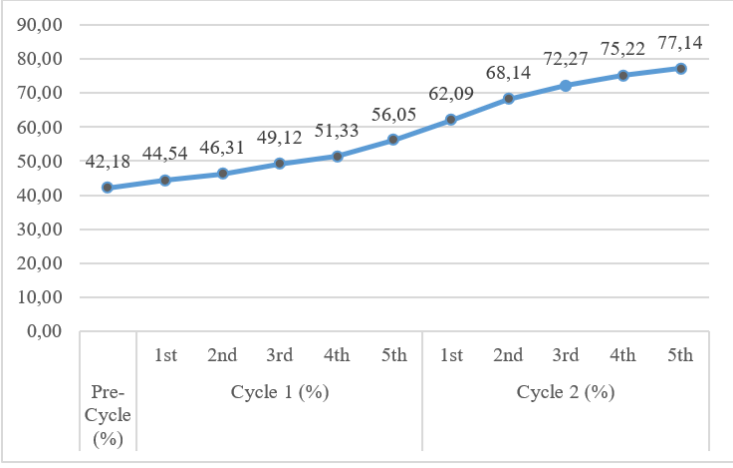

Picture 1. The Students' Activeness in Observation List Each Action

From the above percentage of the students' activeness in the Observation list shown that the students' activeness from each cycle was improved. Each action in the cycles also increased actively. The improvement from pre-cycle, cycle one until cycle 2 shown that students' activeness positively increased. The improvement of students' activeness in observation list from pre-cycle, cycle one, and cycle two could be seen in the following figure:

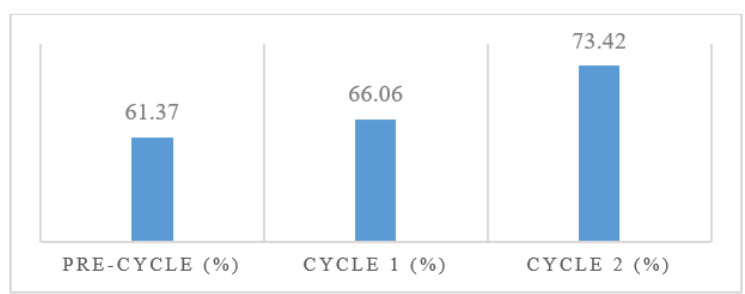

Picture 2. The Students' Activeness in Observation List Each Cycle

By the field notes' data in the first cycle, the students' activities were dominated by the students who were doubt, unconfident, and worried about doing the exercises. The students who were active during the English learning were still less. Hence, the students who had less motivation dominated in the English learning process. In the second cycle, the students started to show their encouragement. They were enthusiastic in participating in class discussion, students persist and try different solutions before seeking help when they have difficulty with a task, students were willing to invest effort and to use the skills they have acquired, students were willing to learn more than is required are reluctant to stop working on a task, even when it is time to move on to something new, and they started to enjoy and enthusiastic in English learning process through mobile phone as learning media. This media encouraged the students' motivation, felt enjoy during the English learning process.

The excellent interaction between teachers and students during the learning process made the students' motivation in learning English vocabulary was increased actively. In cycle 2 , the students more active compared to cycle 1 . The students had a willingness to act and enlarge their English vocabulary skills. In this case, the students were not only enthusiastic but also more courage and more confident in some activities like asking/answering questions and discussion.

The positive response of students toward English vocabulary learning could be shown in the test result that had been done in the pre-cycle, and at the end of each cycle (post-test one and post-test 2). The tests result transformed into a score above. The average of pre-test in pre cycle's score shown 61.37. At the end of cycle 1, post-test 1 shown 66.05 , and at the end of cycle 2 (post-test 2) was 73.42. The results of the test carried out by students' improvement. It means that the students' achievement was improved through mobile phones as learning media in English vocabulary learning. It could be seen from average the students' test result as followed:

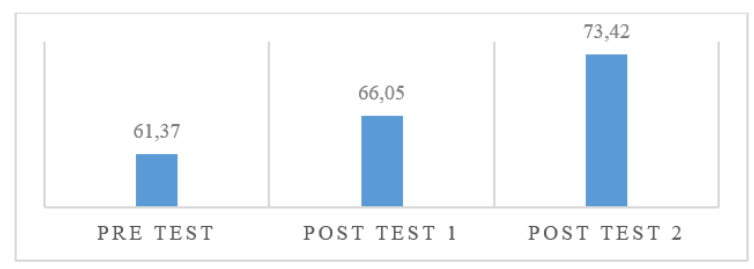

Picture 3. The students' test result list Each Cycle

The success of those cycles was also supported by data from the questionnaire given to the students after the cycle ends. Questionnaire data have shown that the level of student motivation increased through mobile phones as learning media English vocabulary media. It can be seen from the participation of the students in filling out the questionnaire sheet. Questionnaire data have shown the results that most students feel motivated during English vocabulary learning, so their score obtained is also sufficient to them. 
Table 1. Questionnaire Result

\begin{tabular}{|c|c|c|}
\hline No & Item & Percentage \\
\hline 1 & $\begin{array}{l}\text { The students feel motivated and } \\
\text { persistent in following English } \\
\text { vocabulary learning through } \\
\text { mobile phones as learning } \\
\text { media. }\end{array}$ & $76.64 \%$ \\
\hline 2 & $\begin{array}{l}\text { The students feel interested in } \\
\text { learning mobile phones as } \\
\text { learning media used by teachers. }\end{array}$ & $75,22 \%$ \\
\hline 3 & $\begin{array}{l}\text { The students always pay } \\
\text { attention to all their teacher's } \\
\text { explanations. }\end{array}$ & $74.34 \%$ \\
\hline 4 & $\begin{array}{l}\text { The students can do the tasks } \\
\text { well through mobile phones as } \\
\text { learning media. }\end{array}$ & $77.17 \%$ \\
\hline 5 & $\begin{array}{l}\text { The students have done the task } \\
\text { on time through mobile phones } \\
\text { as learning media. }\end{array}$ & $76.64 \%$ \\
\hline 6 & $\begin{array}{l}\text { The students to be more active } \\
\text { on tasks group (discussion). }\end{array}$ & $73.98 \%$ \\
\hline 7 & $\begin{array}{l}\text { The students always pay } \\
\text { attention to the teacher's } \\
\text { instructions. }\end{array}$ & $77.17 \%$ \\
\hline 8 & $\begin{array}{l}\text { The student's acquisition results } \\
\text { were the highest. }\end{array}$ & $75.75 \%$ \\
\hline 9 & $\begin{array}{l}\text { The students are trying to solve } \\
\text { problems that are difficult. }\end{array}$ & $74.34 \%$ \\
\hline 10 & $\begin{array}{l}\text { The students assume that mobile } \\
\text { phone as learning media is } \\
\text { beneficial for them. }\end{array}$ & $75.58 \%$ \\
\hline 11 & $\begin{array}{l}\text { The students assume that mobile } \\
\text { phone as learning media is } \\
\text { beneficial for them. }\end{array}$ & $75.58 \%$ \\
\hline 12 & $\begin{array}{l}\text { The students believe they will } \\
\text { be able to master the material } \\
\text { better using the mobile phone as } \\
\text { learning media. }\end{array}$ & $70.63 \%$ \\
\hline 13 & $\begin{array}{l}\text { The students believe they will } \\
\text { be successful in the exams. }\end{array}$ & $74.51 \%$. \\
\hline 14 & $\begin{array}{l}\text { The students become motivated } \\
\text { to find other sources in the } \\
\text { context of an understanding of } \\
\text { the material. }\end{array}$ & $73.27 \%$, \\
\hline 15 & $\begin{array}{l}\text { The students will not hesitate to } \\
\text { ask if they find difficulty in } \\
\text { learning activities. }\end{array}$ & $73.81 \%$ \\
\hline 16 & $\begin{array}{l}\text { The students found that the } \\
\text { comments of teachers can } \\
\text { motivate them to be better so } \\
\text { that the student can complete } \\
\text { the task and were satisfied with } \\
\text { the results achieved. }\end{array}$ & $73.81 \%$ \\
\hline 17 & $\begin{array}{l}\text { The mobile phone, as learning } \\
\text { media used by teachers, greatly } \\
\text { assist students in acquiring the } \\
\text { highest score in English } \\
\text { vocabulary learning. }\end{array}$ & $74.34 \%$ \\
\hline 18 & The students were satisfied with & $75.93 \%$ \\
\hline
\end{tabular}

\begin{tabular}{|c|c|c|}
\hline No & Item & Percentage \\
\hline & $\begin{array}{l}\text { what they had gained during } \\
\text { English. }\end{array}$ & \\
\hline
\end{tabular}

Students found that they were motivated by the use of mobile phones as learning media used by teachers in assignments and group discussions. Students feel motivated to develop their learning skills so that the learning outcomes they get sufficient.

Based on the data that had been analyzed, the classroom environment was more active and exciting to the students through mobile phones as learning media. The students' vocabulary mastery was improved positively. It could be concluded that mobile phone as learning media was able to use as media in motivating students and improving students' English vocabulary.

\section{CONCLUSION}

The mobile phone as learning media was an English learning media that successfully used in vocabulary learning to become more active and exciting. It is shown in questionnaires' data that $76.64 \%$ proven the students to be more active, and $75.22 \%$ of the students feel interested in vocabulary learning using the mobile phone as learning media by their teacher. So, they always pay attention to the teacher instructions during English vocabulary learning $(74.34 \%) .73 .81 \%$ shown that the students will not hesitate to ask if they find difficulty in learning activities.

The mobile phone as learning media was able to improve students' motivation in English vocabulary learning. The data are taken from the observation list shown that the student's activeness improved in each action of each cycle. The improvement from pre-cycle to cycle 1 was $17.28 \%$, and cycle 2 was $62.26 \%$. This improvement has achieved the criteria of action success as proposed by Suharsimi Arikunto, 2010:13. It means that the percentage of $62.26 \%$ was categorized as "High Level". This result was supported by the data gained from field notes, which showed that most of the students felt enjoy and more motivated with the mobile phone as learning as English learning media. They did not feel worried about doing activities in the class.

Increasing vocabulary mastery of the students can be seen from the result of the tests. It conducted by the students during the research. The result of the students' pre-test was 61.37 , post-test 1 was 66.06 , and post-test 2 was 73.42 . From these tests result, it can be seen that there was an improvement in the 
students' learning outcomes in understanding English vocabulary using the mobile phone as learning media. Moreover, to support the data of improved students' motivation it can be seen in questionnaires that more than $70 \%$ students agreed with mobile phone as learning instructional media used by teachers, greatly assist students in acquiring the highest score in the English vocabulary learning $(74.34 \%)$ and in general the students were satisfied with what they had gained during English vocabulary learning $(75.93 \%)$.

Based on these results, this action research decided that learning English vocabulary through mobile phones as learning media was an exciting alternative learning media that able to motivate the students both acquiring the highest score in their English vocabulary learning. The students activeness improved, which shown that most of the students felt enjoy and more motivated with mobile phone learning as English learning media. They did not feel worried to do learning vocabulary activities in the class using mobile learning.

\section{REFERENCE}

Alfaki, I. M. (2015). Vocabulary input in English language teaching: Assessing the vocabulary load in spine five. International Journal of English Language and Linguistics Research Vol.3,No.1,Pp.1-14. https://doi.org/10.1017/CBO9781107415324.0 04

ALQAHTANI, M. (2015). The importance of vocabulary in language learning and how to be taught. International Journal of Teaching and Education.

https://doi.org/10.20472/te.2015.3.3.002

Boyinbode, O. K., \& Akinyede, R. O. (2008). Mobile Learning: An Application Of Mobile And Wireless Technologies In Nigerian Learning System . 2 . What is M-learning? Journal of Computer Science.

Danesh, A., Inkpen, K., Lau, F., Shu, K., \& Booth, K. (2001). Geney ${ }^{\mathrm{TM}}$ : Designing a collaborative activity for the palm ${ }^{\mathrm{TM}}$ handheld computer. Conference on Human Factors in Computing Systems - Proceedings.

De Brabander, C. J., \& Martens, R. L. (2014). Towards a unified theory of task-specific motivation. In Educational Research Review. https://doi.org/10.1016/j.edurev.2013.11.001
Dorkchandra, D. (2016). The Lexical Approach as Known and Utilized by Thai EFL Teachers. International Journal of English Language Education.

https://doi.org/10.5296/ijele.v4i2.9309

Ellis, R. (1997). The empirical evaluation of language teaching materials. ELT Journal. https://doi.org/10.1093/elt/51.1.36

Heinich, R., Molenda, M., Russell, J., \& Smaldino, S. (2012). Instructional Media and Technology for Learning. International Journal of Distributed and Parallel Systems. https://doi.org/10.1016/J.ARABJC.2011.11.00 8

Nasrollahi, M. A. (2015). A closer look at using Stringer's action research model in improving students' learning. International Journal of Current Research.

Nation, I. S. P., \& Hunston, S. (2013). Learning Vocabulary in Another Language. In Learning Vocabulary in Another Language. https://doi.org/10.1017/cbo9781139858656

Pinkwart, N., Hoppe, H. U., Milrad, M., \& Perez, J. (2003). Educational scenarios for cooperative use of Personal Digital Assistants. Journal of Computer Assisted Learning. https://doi.org/10.1046/j.02664909.2003.00039.x

Sardiman, A. (2016). Interaksi dan Motivasi Belajar Mengajar. In Raja Grafindo Persada.

Stone, A., Briggs, J., \& Smith, C. (2002). SMS and interactivity-some results from the field, and its implications on effective uses of mobile technologies in education. Proceedings - IEEE International Workshop on Wireless and Mobile Technologies in Education, WMTE 2002.

https://doi.org/10.1109/WMTE.2002.1039238

Traxler, J. (2007). Defining, discussing, and evaluating mobile learning: The moving finger writes and having writ... In International Review of Research in Open and Distance Learning. https://doi.org/10.19173/irrodl.v8i2.346 